\title{
Anti-inflammation activity of brazilin in TNF-a induced human psoriasis dermatitis skin model
}

\author{
Da Hee Choi and Hyung Seo Hwang * (1)
}

\begin{abstract}
Psoriasis is a chronic inflammatory skin disease that causes erythema, scale, and invasion due to excessive proliferation of keratinocyte and vascular deformation of the upper part of the dermis. Recently, it has been reported that brazilin, an active compound of Caesalpinia sappan L., possesses anti-inflammatory activity in mouse macrophage. However, little is known about its effect or anti-inflammatory activity on psoriasis dermatitis. Thus, the objective of this study was to determine anti-inflammatory activity of brazilin in TNF-a-induced human keratinocyte (HaCaT) widely used as a model of psoriatic dermatitis. First, CCK-8 assay was performed to determine cytotoxicity of brazilin in $\mathrm{HaCaT}$ cells and cytotoxicity was not observed up to $7 \mu \mathrm{g} / \mathrm{mL}$ concentrations. Brazilin decreased mRNA expres-

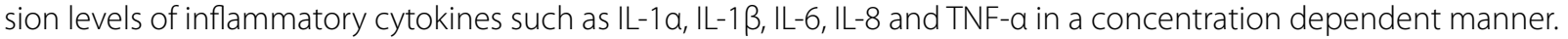
Brazilin also significantly reduced phosphorylation of $\mathrm{I}-\mathrm{KB}$, Akt, and MAPKs such as ERK, JNK, p38 and STAT3 in immortalized human keratinocytes ( $\mathrm{HaCaT}$ ) induced by TNF-a. In addition, inflammation causes the weakness of the skin barrier structure and increase cell permeability, stimulating serious problems in skin moisturizing. Thus, we observed changes of skin permeability in TNF-a induced inflammatory condition through transepithelial electrical resistance (TEER) assay. While TNF-a induced inflammation caused reduction of TEER value (ohm $\left.(\Omega) \times \mathrm{cm}^{2}\right)$, it was recovered by treatment with brazilin in a concentration-dependent manner. These results strongly imply that brazilin can reinforce the skin barrier due to its anti-inflammatory activity. Therefore, brazilin could be a promising candidate for treating psoriasis dermatitis.
\end{abstract}

Keywords: Anti-inflammation, Brazilin, HaCaT, Mitogen-activated protein kinase, Psoriasis, Tumor necrosis factoralpha

\begin{abstract}
Introduction
Inflammation is innate immunity reaction that protects human bodies from external pathogens or tissue damage [1]. Also, it is a cause that exacerbates diverse skin diseases such as psoriasis and atopic dermatitis [2-4]. In particular, psoriasis is a chronic inflammatory skin disease that causes erythema, scale, and invasion due to excessive proliferation of keratinocyte and vascular deformation of the upper part of the dermis $[5,6]$. In a normal immune reaction, if external antigens flow in, antigen-presenting cells (APCs) will deliver antigens
\end{abstract}

*Correspondence: hshwang@semyung.ac.kr

School of Cosmetic Science and Beauty Biotechnology, Semyung

University, 65 Semyungro, Jechon, Chungbuk 27136, Republic of Korea to helper $\mathrm{T}$ cells (Th cells) and induce differentiation to Th1, Th2, and Th17 $[7,8]$. Th1 cells secrete proinflammatory cytokine such as interferon gamma (IFN$\gamma)$, tumor necrosis factor-alpha (TNF- $\alpha$ ), IL-1 $\alpha$, IL-1 $\beta$, IL-6, IL-8, and IL-23 [9]. In particular, IL- $1 \alpha / \beta$ induces differentiation of keratin $6 / 16$ protein by activating nuclear factor-kappa (NF-kB) signal transduction of Th1 cells [10]. On the skin of a psoriasis dermatitis patient, expression of pro-inflammatory cytokines specifically increases, leading to excessive proliferation phenomenon of keratinocyte $[11,12]$. In addition, IL-6, IL-17, IL-22, and transforming growth factor beta (TGF- $\beta$ ) expressed in Th17 cells accelerate psoriatic lesion's inflammatory reaction by activating STAT 
(Signal Transducer and Activator of Transcription) [13-15]. Accordingly, TNF- $\alpha$ inhibitor is most widely used at present as a medicine for psoriasis dermatitis, and TNF- $\alpha$ treated keratinocyte has been used as a psoriasis dermatitis test model in many in vitro studies [16-18]. When TNF- $\alpha$ binds to TNFR (Tumor Necrosis Factor Receptor) in keratinocyte, Akt (Protein kinase B) and IKK (I-KB kinase) protein is activated to phosphorylate I- $\mathrm{KB}$ (Inhibitors kappa B), which then activates NF-kB. This consequentially accelerates expression of inflammatory cytokines such as IL- $1 \alpha$, IL- $1 \beta$, IL-6, IL-8, and TNF- $\alpha$ [19-22]. Also, MAPKs (Mitogen Activated Protein Kinases) made up of ERK, JNK and p38 is located upstream of inflammatory cytokines. Due to activation of TNF- $\alpha$ signal, ERK, JNK, and p38 proteins are phosphorylated and overexpressed in psoriasis dermatitis [23-26].

Caesalpinia sappan L. is a medicinal plant that is distributed in Southeast Asia. Brazilin is the major active compound, which has exhibited various pharmacological effects, including anti-inflammatory and anti-oxidative activities. From previous studies, we have studied on diverse effects of Caesalpinia sappan L. extract and brazilin with human skin cells [27-30]. However, no study has been conducted at all on the effect of brazilin on psoriasis dermatitis which is a typical intractable dermatitis disease. Thus, the objective of this study was to investigate dermatitis improvement effect of brazilin in a model of psoriasis dermatitis which is an intractable skin disease.

\section{Materials and methods Plant material}

Brazilin used in the present study was directly purchased mostly from ChemFaces Biochemical Co. Ltd. (Wuhan, Hubei, China).

\section{Cell culture}

$\mathrm{HaCaT}$ cell which is the human keratinocyte cell line used in the present study was received from the Division of Biotechnology of Korea University. $\mathrm{HaCaT}$ cells were cultured in the condition of $37{ }^{\circ} \mathrm{C}$ and $5 \% \mathrm{CO}_{2}$ using Dulbecco's modified Eagle's medium (Welgene, Kyungsan, Kyungbuk, Korea) mixed with heat-inactivated 10\% Fetal Bovine Serum (FBS, Welgene, Kyungsan, Kyungbuk, Korea), penicillin $100 \mathrm{U} / \mathrm{mL}$ (Gibco, Dublin, Ireland), and streptomycin sulfate $(100 \mu \mathrm{g} / \mathrm{mL})$. In all experiments, $\mathrm{HaCaT}$ cells were treated with TNF- $\alpha$ for inflammatory stimulus and brazilin by concentration at the same time and changes in mRNA and protein levels were compared after a certain period of time.

\section{Cell viability assay}

To determine the effect of TNF- $\alpha$ and brazilin as well as their combination when treated at the same time on cytotoxicity in $\mathrm{HaCaT}$ cells, CCK-8 (Cell counting kit-8 DogenBio, Seoul, Korea) assay was conducted. First, $500 \mu \mathrm{L}$ of $\mathrm{HaCaT}$ cells were seeded into each well of 24-well plates at a density of $5.0 \times 10^{4}$ cells/ well and cultured for $24 \mathrm{~h}$. First, each well was treated with TNF- $\alpha$ at different concentrations (0 to $100 \mathrm{ng} /$ $\mathrm{mL}$ ) using DMEM (FBS free) medium and cells were cultured for $24 \mathrm{~h}$. For cytotoxicity assay of brazilin and TNF- $\alpha$ co-treated group, brazilin and TNF- $\alpha$ were used for treatment at the same time with different concentrations and cells were cultured for $24 \mathrm{~h}$. After removing the supernatant, each well was treated with 500 $\mu \mathrm{L}$ of CCK-8 solution prepared by diluting DMEM: EZ-Cytox at the ratio of 10:1 and cells were cultured for $30 \mathrm{~min}$. Absorbance was then measured at $450 \mathrm{~nm}$ using an ELISA reader (BioTek, Highland Park, USA).

$$
\text { Cell viability (\%) }=\frac{\mathrm{OD}_{\text {sample }}^{\mathrm{a}}-\mathrm{OD}_{\text {blank }}^{\mathrm{b}}}{\mathrm{OD}_{\text {control }}^{\mathrm{c}}-\mathrm{OD}_{\text {blank }}} \times 100
$$

a: absorbance of the group treated with brazilin, b: absorbance of CCK- 8 solution, c: absorbance of the control group.

\section{RNA extraction and Real-time RT-PCR}

$\mathrm{HaCaT}$ cells were seeded into 6-well plates at density of $5 \times 10^{5}$ cells/well and cultured for $24 \mathrm{~h}$. To induce inflammatory stimulus of $\mathrm{HaCaT}$ cells, TNF- $\alpha(20 \mathrm{ng} /$ $\mathrm{mL}$ ) and brazilin were used to treat cells at the same time for $2 \mathrm{~h}$ with different concentrations. Total RNA was extracted using TRIZol reagent (Ambion, Carlsbad, CA, USA). Total RNA was then quantified and $1.5 \mu \mathrm{g}$ of RNA was used to synthesize cDNA using a Revertra ACE kit (Toyobo, OSAKA, Japan) under the following conditions; $42{ }^{\circ} \mathrm{C}$ for $20 \mathrm{~min}, 99^{\circ} \mathrm{C}$ for $5 \mathrm{~min}$, and $4{ }^{\circ} \mathrm{C}$ for $5 \mathrm{~min}$. The synthesized cDNA was used with 100X Tris/EDTA buffer (Sigma aldrich) diluted to $1 \mathrm{X}$ using DEPC water (Sigma aldrich). A StepOne Realtime PCR (Applied Biosystems, Foster city, CA, USA) was used for an RT-RCR experiment. The amount of gene's mRNA expression amplified in real time was comparatively analyzed using a Taqman probe (Applied Biosystems, Foster City, CA, USA) for each gene. Taqman probes used in this study are shown in Table 1.

\section{Western blot analysis}

$\mathrm{HaCaT}$ cells were seeded into 6-well plates at density of $1.0 \times 10^{6} \mathrm{cells} /$ well and cultured for $24 \mathrm{~h}$. For induction 
Table 1 Gene name and assay ID number in real-time PCR analysis

\begin{tabular}{lll}
\hline Symbol & Gene name & Assay ID \\
\hline GAPDH & $\begin{array}{l}\text { Glyceraldehyde 3 phosphate dehydroge- } \\
\text { nase }\end{array}$ & Hs02786624_g1 \\
IL-1a & Interleukin 1 alpha & Hs00174092_m1 \\
IL-1 $\beta$ & Interleukin 1 beta & Hs01555410_m1 \\
IL-6 & Interleukin 6 & Hs00174131_m1 \\
IL-8 & Interleukin 8 & Hs00174103_m1 \\
TNF-a & Tumor necrosis factor alpha & Hs00174128_m1 \\
COX-2 & Prostaglandin-endoperoxide synthase 2 & Hs00153133_m1 \\
\hline
\end{tabular}

of inflammation, TNF- $\alpha(20 \mathrm{ng} / \mathrm{mL})$ and brazilin were used to treat cells at the same time with different concentrations and the cells were cultured for $2 \mathrm{~h}$. After $\mathrm{HaCaT}$ cells stimulated by TNF- $\alpha$ were washed three times with cold $\left(4^{\circ} \mathrm{C}\right)$ PBS (Phosphate Buffered Saline), cells were lysed with $100 \mu \mathrm{L}$ of RIPA lysis buffer $(25 \mathrm{mM}$ Tris. $\mathrm{HCl} \mathrm{pH}$ 7.6, $150 \mathrm{nM} \mathrm{NaCal,} \mathrm{1 \%} \mathrm{NP-40,} \mathrm{1 \%} \mathrm{sodium}$ deoxycholate, $0.1 \%$ SDS, phosphatase inhibitor cocktail, $50 \mathrm{mM}$ EDTA) and stirred for $15 \mathrm{~min}$. Total protein was then obtained after centrifugation in $14,000 \mathrm{rpm}$ for 15 min at $4{ }^{\circ} \mathrm{C}$. After quantifying protein concentration using Bradford (Bio-Rad, California, USA) assay, it was added with laemmli sample buffer $(31.5 \mathrm{mM}$ Tris- $\mathrm{HCl}$, $\mathrm{pH}$ 6.8, 10\% glycerol, 1\% SDS, 0.005\% Bromophenol Blue, Bio-rad, California, USA) and $\beta$-mercaptoethanol and heated at about $95{ }^{\circ} \mathrm{C}$ for $5 \mathrm{~min}$. The protein extract was electrophoresed using 10\% SDS-PAGE gel with Tris/Glycine/SDS running buffer. Proteins separated by size were then transferred to PVDF (Polyvinylidene fluoride) membrane using iBlot dry blotting system (Invitrogen, Calsbad, CA, USA). Membrane was blocked with $10 \%$ skim milk for $1 \mathrm{~h}$ and then incubated with primary antibody at $4{ }^{\circ} \mathrm{C}$ for $1 \mathrm{~h}$. After washing with TBST buffer $(50 \mathrm{mM}$ Tris, $150 \mathrm{mM} \mathrm{NaCl}, 0.1 \%$ Tween 20 , $\mathrm{pH}$ 7.4) 5 times (5 min each), the membrane was then incubated with secondary antibody at $4{ }^{\circ} \mathrm{C}$ followed by washing with TBST five times ( 5 min each wash). The membrane was then developed with Western ECL substrates (Bio-Rad, CA, USA) and images were captured with an image processing device (Microchemi-DNR, Neve Yamin, Israel). The amount of protein expression was quantified and statistically processed using Image J (Image processing and analysis in Java, NIH, Bethesda, MD, USA) program. Antibodies used for the experiment are listed in Table 2.

\section{TEER (transepithelial electrical resistance) assay}

To determine skin barrier control of skin cells, TEER value $\left(\operatorname{ohm}(\Omega) \times \mathrm{cm}^{2}\right)$ of skin was measured using EVOM $^{2}$ equipment (Epithelium Volt Ohm Meter 2, 300523, WPI, Sarasota, FL, USA). First, $\mathrm{HaCaT}$ cells were seeded into $1.12 \mathrm{~cm}^{2}$ sized transwell plates at density of $2.0 \times 10^{4}$ cells/plate and cultured for $24 \mathrm{~h}$ to allow the cells to settle down on the well plates, and TNF- $\alpha$ (20 ng/ $\mathrm{ml}$ ) and brazilin were then used to treat cells for $24 \mathrm{~h}$ with

Table 2 Protein and antibody used in western blot analysis

\begin{tabular}{|c|c|c|}
\hline Symbol & Gene name & Assay ID \\
\hline GAPDH & Glyceraldehyde 3 phosphate dehydrogenase & MA5-15738 \\
\hline $\mathrm{IKBa}$ & Nuclear factor of kappa light polypeptide gene enhancer in B-cells inhibitor, alpha & $39-7700^{a}$ \\
\hline $\mathrm{p}-\mathrm{I} \mathrm{kBa}$ & Phospho - nuclear factor of kappa light polypeptide gene enhancer in B-cells inhibitor, alpha & MA5-15087 \\
\hline$N F-K B$ & Nuclear factor kappa-light-chain-enhancer of activated B cells & PA5-16545 \\
\hline $\mathrm{p}-\mathrm{NF}-\mathrm{kB}$ & Phospho-nuclear factor kappa-light-chain-enhancer of activated B cells & MA5-15160 \\
\hline Akt & Protein kinase B & $2920^{b}$ \\
\hline $\mathrm{p}-\mathrm{Akt}$ & Phospho-protein kinase B & $4052^{b}$ \\
\hline ERK & Extracellular signal-regulated kinase & $13-6200^{a}$ \\
\hline$p-E R K$ & Phospho-extracellular signal-regulated kinase & $700012^{\mathrm{a}}$ \\
\hline JNK & c-Jun N-terminal kinase & MA5-15183 \\
\hline p-JNK & Phospho-c-Jun N-terminal kinase & MA5-15228 \\
\hline p38 & p38 mitogen-activated protein kinase & $9212^{b}$ \\
\hline p-p38 & Phospho-p38 mitogen-activated protein kinase & $9211^{b}$ \\
\hline STAT3 & Signal transducer and activator of transcription 3 & $4904^{b}$ \\
\hline p-STAT3 & Phospho-signal transducer and activator of transcription 3 & $9145^{b}$ \\
\hline \multicolumn{2}{|c|}{ Goat anti-Rabbit lgG $(H+L)$ Secodary Antibody, HRP } & $31460^{a}$ \\
\hline \multicolumn{2}{|c|}{ Goat anti-Mouse $\operatorname{lgG}(\mathrm{H}+\mathrm{L})$ Secodary Antibody, HRP } & $31430^{a}$ \\
\hline
\end{tabular}

\footnotetext{
${ }^{\text {a }}$ Invitrogen ${ }^{\mathrm{TM}}$
}

b Cell signaling ${ }^{\mathrm{TM}}$ 
different concentrations. For transwell plates, $500 \mu \mathrm{L}$ was added to each insert well and $1500 \mu \mathrm{L}$ was added to each receiver well. During TEER measurement, an environmental condition of $36.5{ }^{\circ} \mathrm{C}$ was maintained to be the same as the incubator environment to minimize experimental error resulting from temperature difference from the outside. The value of $\mathrm{EVOM}^{2} \mathrm{~m}$ on the LCD display window was corrected to ' 0 ' before measurement. All measurements were completed within 5 min by perpendicularly inserting an STX2 electrode into the insert well and receiver well of each treatment group of transwell plate. Experimental values were statistically processed based on measured values by performing measurements repeatedly three times.

\section{Statistical processing}

All experiments of the present study were repeated three times or more. For statistical processing, students t-tests were conducted for results obtained using mean values and standard deviations. Result was judged to be statistically significant if $p$ value was smaller than 0.05 .

\section{Results and discussion}

Brazilin, an indicator of Caesalpinia sappan L., is known to have anti-aging, whitening, anti-inflammatory and anti-microbial effects on the skin. Human keratinocytes induce an inflammatory reaction by secreting various types of inflammatory cytokines such as TNF- $\alpha$, IL- 1 , IL-6, IL-7, IL-8, IL-17, and IL-21 due to external stimulus. In particular, TNF- $\alpha$ is an important cytokine that engages in pathogenesis of psoriasis and various skin diseases. To observe cytotoxicity of brazilin and TNF- $\alpha$ to $\mathrm{HaCaT}$ cells, CCK-8 assay was conducted. No cytotoxicity of TNF- $\alpha$ was observed at concentration up to $100 \mathrm{ng} /$ $\mathrm{mL}$ condition when $\mathrm{HaCaT}$ cells were treated with TNF- $\alpha$ alone. Thus, TNF- $\alpha$ was set as the concentration $(20 \mathrm{ng} / \mathrm{mL}$ ) on results of preceding studies (Fig. 1a). Cell survival rate up to about $95.2 \pm 2.3 \%$ was observed when cells were treated with TNF- $\alpha(20 \mathrm{ng} / \mathrm{mL})$ and brazilin ( 0 to $7 \mu \mathrm{g} / \mathrm{mL}$ ) at the same time. Thus, concentrations of TNF- $\alpha$ and brazilin were set to be $20 \mathrm{ng} / \mathrm{mL}$ and $7 \mu \mathrm{g} / \mathrm{mL}$ for all further experiments, respectively (Fig. 1b).

To verify anti-inflammatory regulation of human skin by brazilin, we used a TNF- $\alpha$ induced $\mathrm{HaCaT}$ cell as a psoriasis dermatitis in vitro test model [16-18]. First, we performed RT-PCR to determine mRNA expression levels of IL- $1 \alpha$, IL-1 $1 \beta$, IL-6, IL- 8 , TNF- $\alpha$ and COX-2 genes as pro-inflammatory cytokines related to psoriasis dermatitis. mRNA expression levels of IL- $1 \alpha$ in the group treated with TNF- $\alpha(20 \mathrm{ng} / \mathrm{mL})$ alone were increased $4.60 \pm 1.6$ times compared to those in the untreated group, confirming that inflammatory reaction was normally induced in $\mathrm{HaCaT}$ cells. Here, quercetin $(7 \mu \mathrm{g} /$
$\mathrm{mL}$ ) was used as a positive control for anti-inflammatory activity [31]. After treating cells with TNF- $\alpha(20 \mathrm{ng} / \mathrm{mL})$ and quercetin at the same time, mRNA expression levels of IL- $1 \alpha$ were decreased by about $33.2 \pm 0.7 \%$ compared to those in the group treated with TNF- $\alpha$ alone. After cells were treated with TNF- $\alpha(20 \mathrm{ng} / \mathrm{mL})$ and brazilin at concentrations of $1.75,3.5$ and $7 \mu \mathrm{g} / \mathrm{mL}$, IL- $1 \alpha$ mRNA expression levels were significantly decreased by $27.5 \pm 0.4 \%, 28.2 \pm 0.9 \%$, and $59.2 \pm 0.4 \%$, respectively (Fig. 1c). IL-1 $\beta$ mRNA expression level in the group treated with TNF- $\alpha$ alone was increased $3.17 \pm 0.6$ times. It was decreased by about $44.6 \pm 0.4 \%$ in quercetin. IL- $1 \beta$ mRNA expression levels in groups treated with TNF- $\alpha$ $(20 \mathrm{ng} / \mathrm{mL})$ and brazilin at concentrations of $1.75,3.5$, and $7 \mu \mathrm{g} / \mathrm{mL}$ were significantly decreased by $23.5 \pm 0.2 \%$, $26.9 \pm 0.3 \%$, and $53.2 \pm 0.3 \%$, respectively (Fig. 1d). IL-6 expression was increased $8.11 \pm 1.6$ times in the group treated with TNF- $\alpha$. Its expression level was decreased by about $44.8 \pm 30.5 \%$ in quercetin group which was the positive control. IL-6 expression levels in groups treated with TNF- $\alpha$ and brazilin at concentrations of 1.75, 3.5, and $7 \mu \mathrm{g} / \mathrm{mL}$ were decreased by $15.7 \pm 1.6 \%, 17.3 \pm 0.9 \%$, and $39.8 \pm 0.4 \%$, respectively, compared to those in the group treated with TNF- $\alpha$ alone (Fig. 1e). IL-8 expression levels in groups treated with TNF- $\alpha$ and brazilin at concentrations of 3.5 and $7 \mu \mathrm{g} / \mathrm{mL}$ were decreased by about $22.4 \pm 6.4 \%$ and $53.7 \pm 3.5 \%$, respectively, compared to those in the group treated with TNF- $\alpha$ alone (Fig. 1f). TNF- $\alpha$ gene expression was increased $47.64 \pm 4.8$ times in the group treated with TNF- $\alpha$. Its expression levels in groups treated with TNF- $\alpha$ and brazilin at concentrations of $1.75,3.5$, and $7 \mu \mathrm{g} / \mathrm{mL}$ were decreased by $23.0 \pm 5.2 \%$, $18.7 \pm 5.6 \%$, and $34.9 \pm 3.5 \%$, respectively, than those in the group treated with TNF- $\alpha$ alone (Fig. 1g). Similar result was observed for COX-2 gene expression under the same condition (Fig. 1h). These results confirmed that brazilin could significantly inhibit mRNA expression of inflammatory cytokines in a concentration-dependent manner.

Activation of NF- $\mathrm{KB}$ is known to be controlled by IKK (I-kB kinase) and Akt (protein kinase B) [32]. Accordingly, since inhibition of mRNA expression of proinflammatory cytokines by brazilin was observed in TNF- $\alpha$ induced human keratinocyte cell line, a study on transcriptional regulation of pro-inflammatory cytokines was conducted. First, changes in amounts of $\mathrm{I}-\mathrm{KB}$ and NF- $\mathrm{KB}$ protein expression were checked in $\mathrm{HaCaT}$ cells activated with TNF- $\alpha$ through western blotting. As a result, while protein expression of $\mathrm{I}-\mathrm{k} B$ was the same, protein expression of phosphorylated $I-\kappa B$ was increased by treatment with TNF- $\alpha$ in comparison with that of untreated group. In the group treated with brazilin and TNF- $\alpha$ at the same time, 

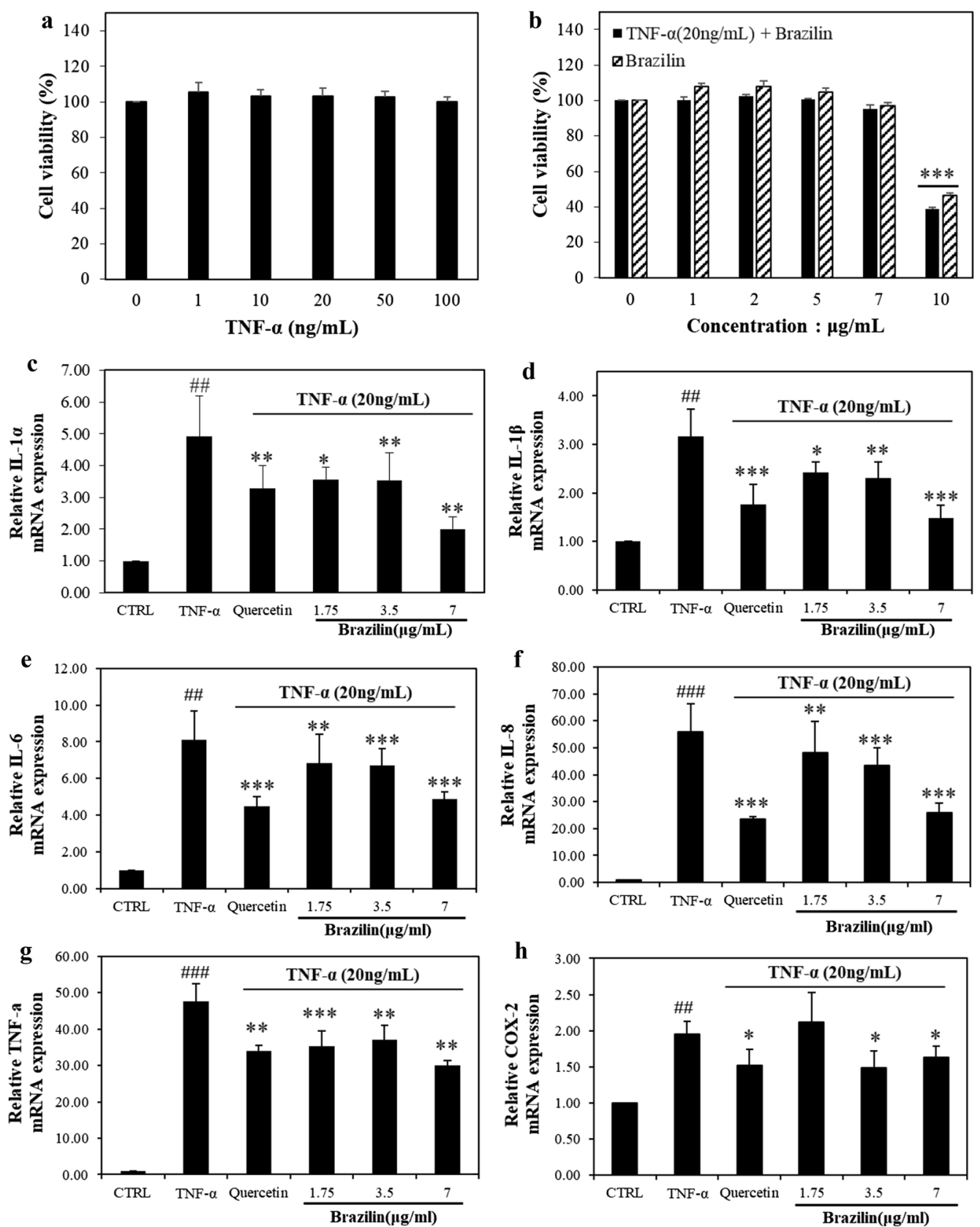

Fig. 1 Viability of HaCaT cells after treatment with TNF- $a$ and brazilin. CCK-8 assay was performed to investigate the anti-inflammatory effect of brazilin and determine the maximum concentration of brazilin for treating cells without inducing cytotoxicity (a, b). Brazilin suppressed mRNA expression of pro-inflammatory cytokines on TNF-a induced HaCaT cells. IL-1a (c), IL-1 $\beta$ (d), IL-6 (e), IL-8 (f), TNF-a (g), and COX-2 (h) gene expression levels were examined by RT-PCR. HaCaT cells were stimulated with the indicated concentration of brazilin in the presence of TNF-a (20 ng/ml) for $2 \mathrm{~h}$ and mRNA expression levels. Data are presented as mean \pm S.D of three experiments. ${ }^{\# \#} \mathrm{p}<0.01$, compared to control, ${ }^{*} p<0.05,{ }^{* *} p<0.01$, ${ }^{* * *} p<0.001$, compared to TNF-a treated group

phosphorylation of $\mathrm{I}-\mathrm{k} B$ was inhibited as the concentration of brazilin was increased (Fig. 2a). After analyzing the amount of protein expression using Image J program, it was found that protein expression of phosphorylated $\mathrm{I}-\mathrm{k} B$ was decreased by brazilin in a concentration-dependent manner (Fig. 2b). However, after checking protein expression of NF- $\mathrm{kB}$ under the same condition, there was no change in phosphorylated NF- $\mathrm{KB}$ after treatment (Fig. 2c, d). Thus, brazilin specifically engaged only in the control of I- $\kappa \mathrm{B}$ protein phosphorylation, not in NF-kB. As result of checking with Akt protein located in the upper stream of NF-kB, it 

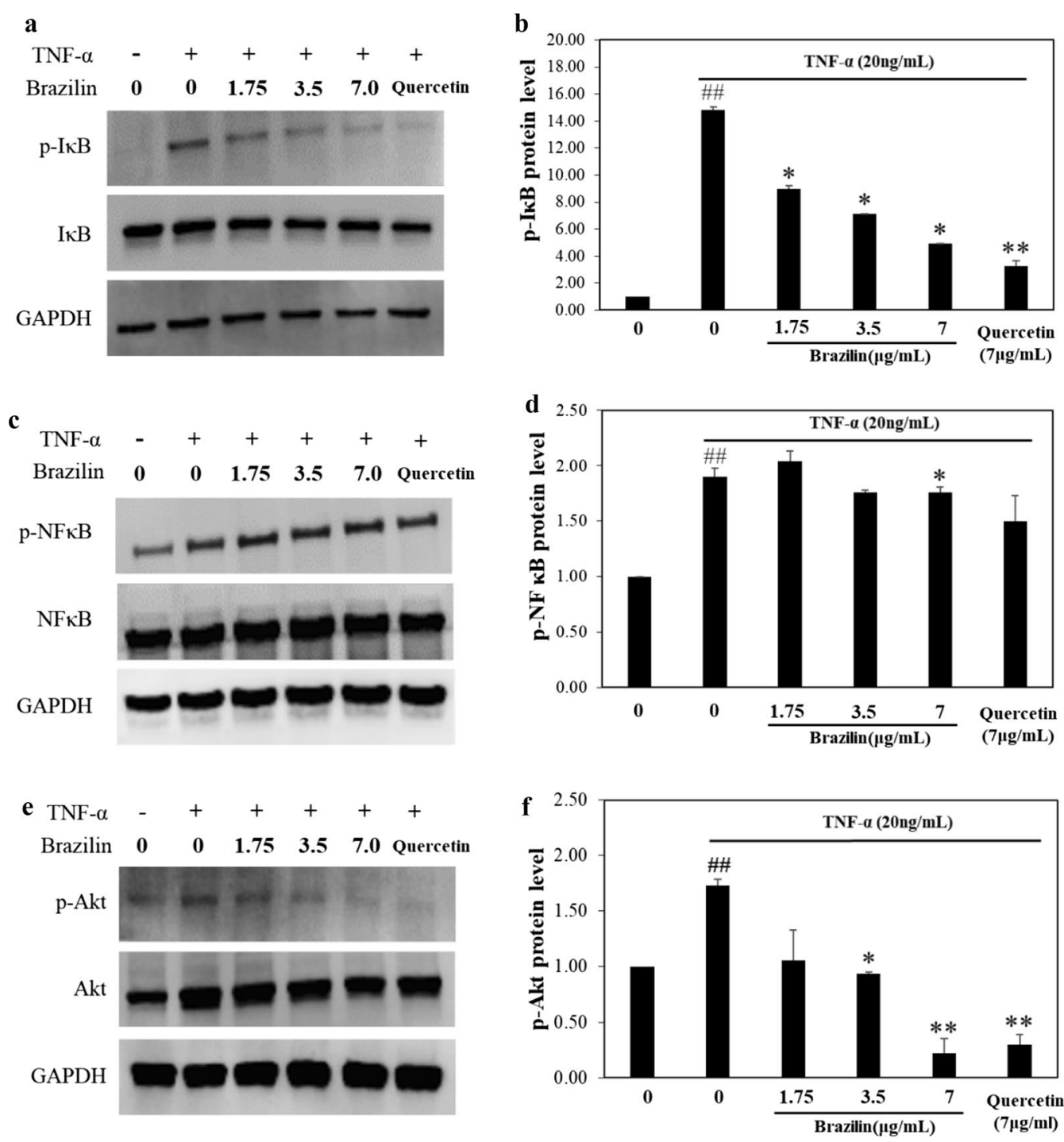

Fig. 2 Brazilin suppressed phosphorylation of $\mathrm{k} B$ and Akt, not NF-KB, in TNF-a stimulated $\mathrm{HaCaT}$ cells. Cells were treated with each concentration of brazilin in the presence of TNF-a $(20 \mathrm{ng} / \mathrm{ml})$ for $2 \mathrm{~h}$. Brazilin suppresses phosphorylation of IkB in TNF-a stimulated HaCaT cells in a concentration-dependent manner (a), but not NF-KB (c). The function of brazilin on inhibiting Akt phosphorylation in TNF-a stimulated HaCaT cells (e). Quantitative assay of p-IKB (b), p-NF-kB (d) and p-Akt (f) with image J program. Data are presented as mean \pm S.D. of triplicate determinations. ${ }^{\#} \mathrm{p}<0.01$, compared to control, ${ }^{*} \mathrm{p}<0.05,{ }^{* *} \mathrm{p}<0.01$ compared to TNF-a group

was confirmed that its protein expression was increased in the group treated with TNF- $\alpha$ compared to that in the untreated group. In addition, protein expression of phosphorylated Akt was decreased by brazilin (Fig. 2e, f). From these results, we could understand that the brazilin inhibit phosphorylation of I- $k B$ by down-regulating Akt phosphorylation under inflammatory signaling pathway induced by TNF- $\alpha$, thus inhibiting the expression of pro-inflammatory cytokines.
Moreover, to confirm association with MARK in the control of inflammation by brazilin, phosphorylation control of MAPKs (ERK, JNK, and p38) was checked after treating $\mathrm{HaCaT}$ cells activated by TNF- $\alpha$. After treating cells with both TNF- $\alpha$ and brazilin, protein expression of phosphorylated ERK was decreased by brazilin (Fig. 3a). As a result of quantifying phosphorylated ERK with Image J, the same result was obtained (Fig. 3b). Phosphorylation of JNK protein was also increased in the group treated with TNF- $\alpha$ and decreased by brazilin in 


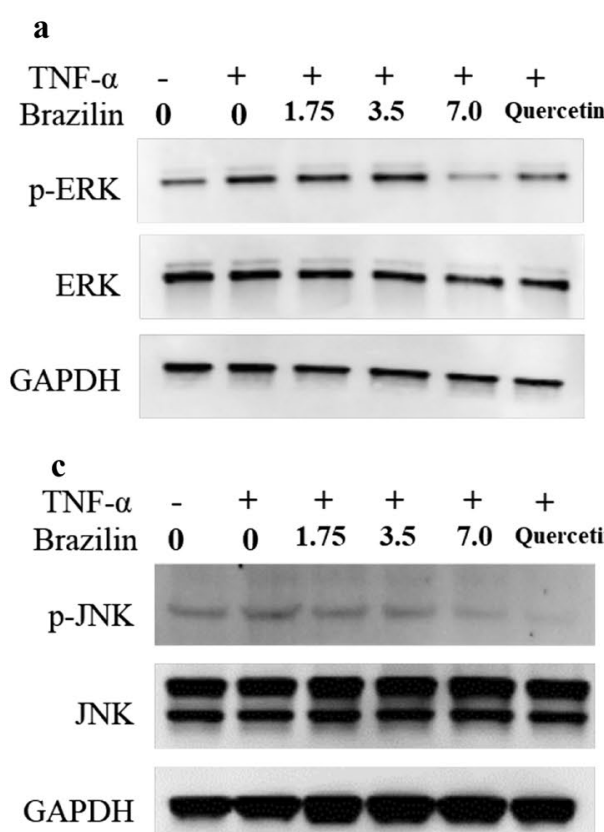

e

$\mathrm{TNF}-\alpha-+\quad+\quad+\quad+\quad+$ $\begin{array}{lllllll}\text { Brazilin } & 0 & 0 & 1.75 & 3.5 & 7.0 & \text { Quercetin }\end{array}$

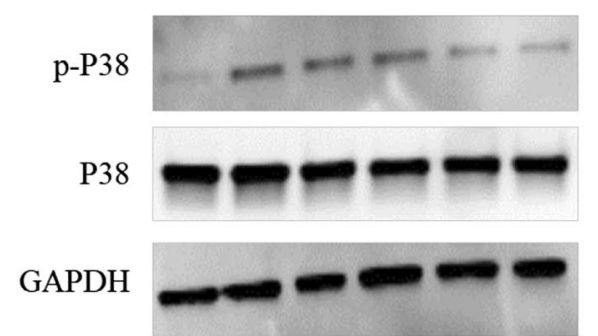

g
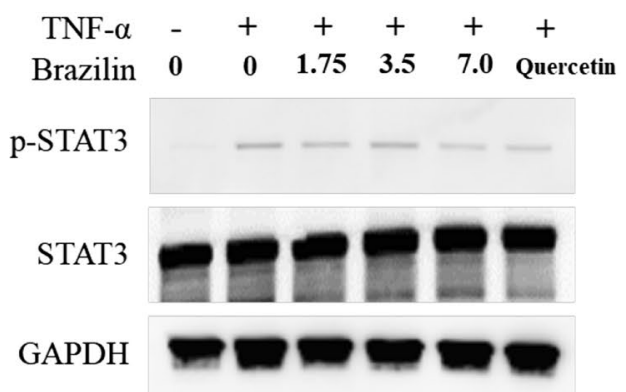
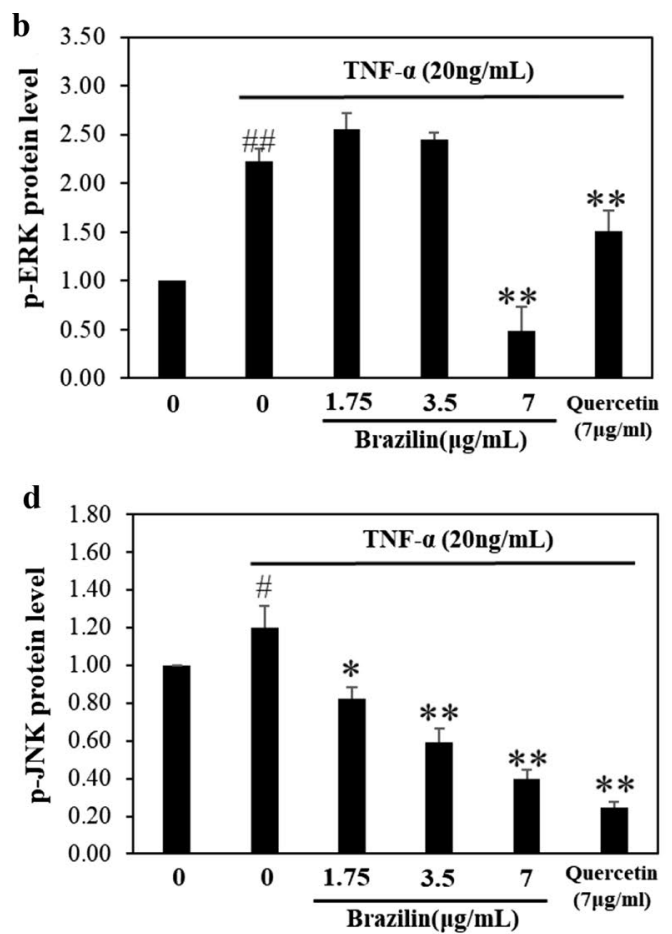

f

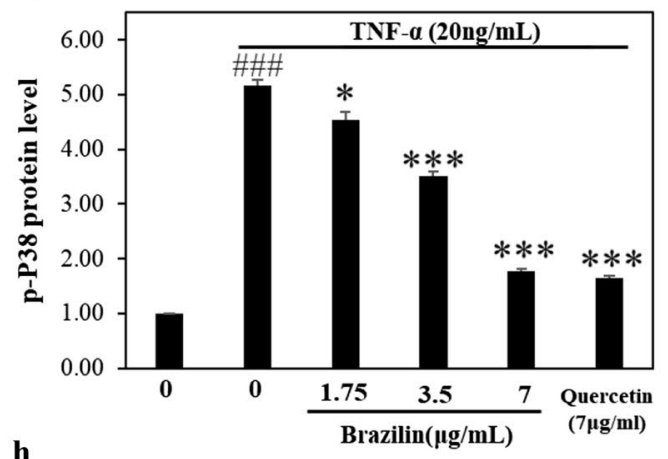

h

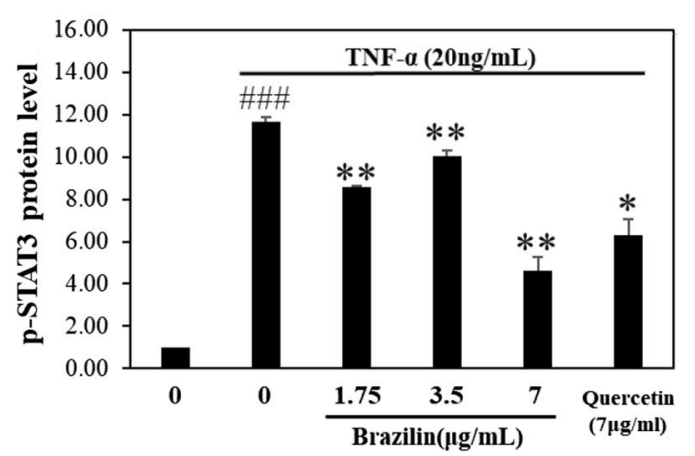

Fig. 3 Brazilin down-regulated phosphorylation of MAPK (ERK, p38, JNK) and STAT3 proteins related to TNF-a signal transduction in HaCaT cells. The phosphorylated protein expression of ERK, p38, and JNK, STAT3 were decreased when brazilin concentration was increased $(\mathbf{a}, \mathbf{c}, \mathbf{e}, \mathbf{g})$. There were comparisons of ERK, JNK and p38, STAT3 phosphorylation by protein quantification using image J program $(\mathbf{b}, \mathbf{d}, \mathbf{f}, \mathbf{h})$. Data are presented as mean \pm S.D. of triplicate determinations. ${ }^{\# \#} p<0.01$, ${ }^{\# \#} p<0.001$, compared to control, ${ }^{*} p<0.05,{ }^{* *} p<0.01,{ }^{* * *} p<0.001$ compared to TNF-a group 


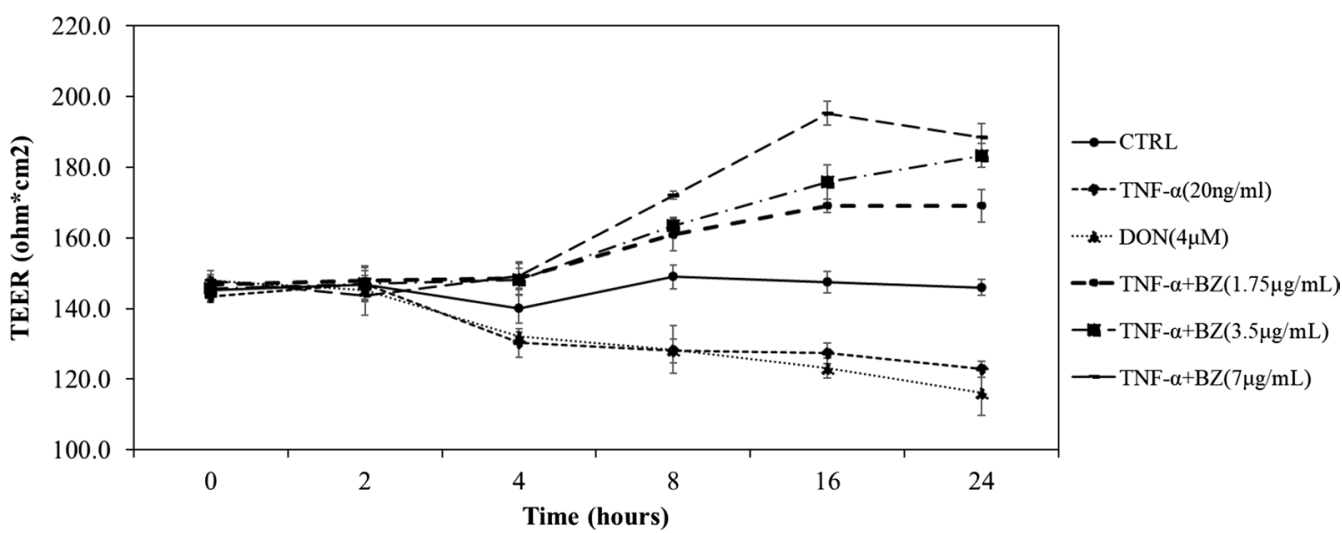

Fig. 4 The TEER value was measured to verify the effect of brazilin on epithelial resistance in the presence of TNF-a. TNF-a induced inflammation caused the decrease of TEER value as time dependent manner. Also, DON used as a negative control showed same pattern with TNF-a. However, co-treatment with TNF-a $(20 \mathrm{ng} / \mathrm{mL})+$ Brazilin $(7 \mu \mathrm{g} / \mathrm{mL})$ significantly increased TEER of HaCaT cell as dose dependent manner. Results are presented as the mean \pm S.D. of the percentage of control density (O.D) in triplicate

a concentration-dependent manner (Fig. 3c, d). Protein expression of phosphorylated p38 was also inhibited by brazilin in a concentration dependent manner in comparison with that in the group treated with TNF- $\alpha$ (Fig. 3e, f). These results demonstrate that brazilin can specifically inhibit phosphorylation of MAPKs (ERK, JNK, and p38) induced by inflammatory reaction.

In the pathogenesis of psoriasis dermatitis, STAT3 phosphorylation is very important in the signal transduction process of IL- 6 and IL-10 receptors. Therefore, we observed STAT phosphorylation after treatment with brazilin in TNF- $\alpha$ induced $\mathrm{HaCaT}$ cells. The amount of STAT3 protein expression under the condition of TNF- $\alpha$ treatment was the same irrespective of brazilin treatment. However, expression of phosphorylated STAT3 protein under the same condition was increased after treatment with TNF- $\alpha$. After treatment with TNF- $\alpha$ and brazilin at concentrations of $1.75,3.5$, and $7 \mu \mathrm{g} / \mathrm{mL}$, phosphorylation of STAT3 was decreased compared to that in the group treated with TNF- $\alpha$ alone (Fig. 3g). As a result of quantitative analysis, the amount of phosphorylated STAT3 protein expression was inhibited about $60.3 \pm 0.3 \%$ by brazilin at $7 \mu \mathrm{g} / \mathrm{mL}$ concentration (Fig. $3 \mathrm{~h}$ ). These results confirmed that brazilin had anti-inflammation effect on psoriasis dermatitis by inhibiting phosphorylation of STAT3 protein in TNF- $\alpha$ induced HaCaT cell line.

Inflammatory reaction of skin impairs skin barrier by weakening the function of tight junction proteins [33]. Therefore, we used TEER assay technique to observe the effect of brazilin on the skin barrier in the TNF- $\alpha$ induced keratinocytes. Treatment was conducted with TNF- $\alpha(20 \mathrm{ng} / \mathrm{mL})$ and $1.75,3.5$, and $7 \mu \mathrm{g} / \mathrm{mL}$ of brazilin respectively at the same time and then TEER value $(\mathrm{ohm}$ $(\Omega) \times \mathrm{cm}^{2}$ ) was measured after $0,2,4,8,16$, and maximum $24 \mathrm{~h}$. Deoxynivalenol (DON), a kind of mycotoxin, was used as a negative control in TEER assay [34]. As a result of experiment, no change in TEER value was observed in all groups treated with $4 \mu \mathrm{M}$ DON, TNF- $\alpha$, and brazilin for $2 \mathrm{~h}$. However, from $4 \mathrm{~h}$ after treatment, TEER value $\left(\mathrm{ohm}(\Omega) \times \mathrm{cm}^{2}\right)$ started to decrease in group treated with TNF- $\alpha$, suggesting weakening of skin barrier caused by inflammation. Under the test condition of $8 \mathrm{~h}$, while TEER value decreased to about $128\left(\mathrm{ohm}(\Omega) \times \mathrm{cm}^{2}\right)$ in group treated with DON or TNF- $\alpha$, it was increased to 161,164 , and $172\left(\mathrm{ohm}(\Omega) \times \mathrm{cm}^{2}\right)$ in groups treated with brazilin at $1.75,3.5$, and $7 \mu \mathrm{g} / \mathrm{mL}$, respectively. Under the test condition of $16 \mathrm{~h}$, TEER values of groups treated with brazilin at $1.75,3.5$, and $7 \mu \mathrm{g} / \mathrm{mL}$ were increased to 171,176 , and $195\left(\mathrm{ohm}(\Omega) \times \mathrm{cm}^{2}\right)$, independently. Also, under the test condition of $24 \mathrm{~h}$, TEER values of values of groups treated with brazilin at $1.75,3.5$, and $7 \mu \mathrm{g} / \mathrm{mL}$ were increased to 169,183 , and $189\left(\mathrm{ohm}(\Omega) \times \mathrm{cm}^{2}\right)$, individually, compared to that in the group treated with TNF- $\alpha$. These results confirm that TNF- $\alpha$ induced inflammatory reaction weakens skin barrier and its weakness could be recovered by antiinflammatory activity of brazilin (Fig. 4).

This study presents the possibility to utilize brazilin as a natural material for improving psoriasis dermatitis due to its anti-inflammatory and skin barrier strengthening effects on keratinocytes. In the treatment for psoriasis dermatitis, it's mainly used steroids, vitamin D derivatives as well as methotrexate, cyclosporin. Recently, monoclonal TNF- $\alpha$ inhibitors such as adalimumab, infliximab, and etanercept have been developed. However, several side effects and cancer risks are reported along with urticaria and erythema reactions due to increased skin infections. So, brazilin, based on a natural product, showed antioxidant, antibacterial and TNF- $\alpha$-derived anti-inflammatory activity and is expected to be used as a substitute for TNF- $\alpha$ inhibitors. 
In the future, we will study the efficacy of brazilin in an animal model of psoriasis dermatitis, an intractable skin disease, and try to identify the modulation of psoriasis related cytokines secretion in Th17 cells and a formulation study for transdermal absorption of brazilin [35]. Based on these results, it is expected that it will be developed as an effective treatment for psoriasis dermatitis if clinical trials are conducted for patients with psoriasis dermatitis.

\section{Acknowledgements}

This study was supported by Research project of Semyung University, South Korea (2019).

\section{Authors' contributions}

DHC and HSH designed all of the experiments and drafted the manuscript. $\mathrm{DHC}$ performed the experiments. Both authors read and approved the final manuscript.

\section{Competing interests}

The authors declare that they have no competing interests.

Received: 10 July 2019 Accepted: 4 September 2019

Published online: 21 September 2019

\section{References}

1. Bradley JR (2008) TNF-mediated inflammatory disease. J Pathol 214:149-160

2. Choi DH, Cho UM, Hwang HS (2018) Anti-inflammation effect of rebaudioside $A$ by inhibition of the MAPK and NF-KB signal pathway in RAW264. 7 macrophage. J Appl Biol Chem 61:205-211

3. Patel TN, Shishehbor MH, Bhatt DL (2007) A review of high-dose statin therapy: targeting cholesterol and inflammation in atherosclerosis. Eur Heart J 28:664-672

4. Yu S, Li Y, Zhou Y, Follansbee T, Hwang ST (2019) Immune mediators and therapies for pruritus in atopic dermatitis and psoriasis. J Cutan Immunol Allergy 2:4-14

5. Naldi L, Gambini D (2007) The clinical spectrum of psoriasis. Clin Dermatol 25:510-518

6. Son ED, Kim HJ, Park T, Shin K, Bae IH, Lim KM, Lee TR (2014) Staphylococcus aureus inhibits terminal differentiation of normal human keratinocytes by stimulating interleukin-6 secretion. J Dermatol Sci 74:64-71

7. Kryczek I, Wei S, Gong W, Shu X, Szeliga W, Vatan L, Zou W (2008) Cutting edge: IFN- $\gamma$ enables APC to promote memory Th17 and abate Th1 cell development. J Immunol 181:5842-5846

8. Baliwag J, Barnes DH, Johnston A (2015) Cytokines in psoriasis. Cytokine 73:342-350

9. Gianello V, Salvi V, Parola C, Moretto N, Facchinetti F, Civelli M, Sozzani S (2019) The PDE4 inhibitor CHF6001 modulates pro-inflammatory cytokines, chemokines and Th1-and Th17-polarizing cytokines in human dendritic cells. Biochem Pharmacol 163:371-380

10. Sun Y, Zhang J, Zhai T, Li H, Li H, Huo R, Teng J (2017) CCN1 promotes $\mathrm{IL}-1 \beta$ production in keratinocytes by activating p38 MAPK signaling in psoriasis. Sci Rep 7:43310

11. Blauvelt A, Hwang ST, Udey MC (2003) Allergic and immunologic diseases of the skin. J Allergy Clin Immunol 111:S560-S570

12. Guttman-Yassky E, Nograles KE, Krueger JG (2011) Contrasting pathogenesis of atopic dermatitis and psoriasis_part I: clinical and pathologic concepts. J Allergy Clin Immunol 127:1110-1118

13. Cho KA, Kim JY, Woo SY, Park HJ, Lee KH, Pae CU (2012) Interleukin-17 and interleukin-22 induced proinflammatory cytokine production in keratinocytes via inhibitor of nuclear factor $\mathrm{KB}$ kinase-a expression. Ann Dermatol 24:398-405

14. Shi $X$, Jin L, Dang E, Chang T, Feng Z, Liu Y, Wang G (2011) IL-17A upregulates keratin 17 expression in keratinocytes through STAT1-and STAT3-dependent mechanisms. J Invest Dermatol 131(12):2401-2408
15. Hunter CA, Jones SA (2015) IL-6 as a keystone cytokine in health and disease. Nat Immunol 16:448-457

16. Sun W, Gao Y, Yu X, Yuan Y, Yi J, Zhang Z, Cha X (2018) 'Psoriasis 1'reduces psoriasis-like skin inflammation by inhibiting the VDR-mediated nuclear NF-KB and STAT signaling pathways. Mol Med Rep 18:2733-2743

17. Xiong H, Xu Y, Tan G, Han Y, Tang Z, Xu W, Guo Q (2015) Glycyrrhizin ameliorates imiquimod-induced psoriasis-like skin lesions in BALB/C mice and inhibits TNF-a-induced ICAM-1 expression via NF-KB/MAPK in HaCaT cells. Cell Physiol Biochem 35:1335-1346

18. Bocheńska K, Smolińska E, Moskot M, Jakóbkiewicz-Banecka J, GabigCimińska M (2017) Models in the research process of psoriasis. Int J Mol Sci $18: 2514$

19. Baud V, Karin M (2001) Signal transduction by tumor necrosis factor and its relatives. Trends Cell Biol 11:372-377

20. Arnott $\mathrm{CH}$, Scott KA, Moore RJ, Robinson SC, Thompson RG, Balkwill FR (2004) Expression of both TNF-a receptor subtypes is essential for optimal skin tumour development. Oncogene 23:1902-1910

21. Bachelez H (2005) Immunopathogenesis of psoriasis: recent insights on the role of adaptive and innate immunity. J Autoimmun 25:69-73

22. Wang A, Wej J, Lu C, Chen H, Zhong X, Lu Y, Han L (2019) Genistein suppresses psoriasis-related inflammation through a STAT3-NF-KB-dependent mechanism in keratinocytes. Int Immunopharmacol 69:270-278

23. Chen G, Goeddel DV (2002) TNF-R1 signaling: a beautiful pathway. Science 296:1634-1635

24. Roux PP, Blenis J (2004) ERK and p38 MAPK-activated protein kinases: a family of protein kinases with diverse biological functions. Microbiol Mol Biol Rev 68:320-344

25. Arthur JSC, Darragh J (2006) Signaling downstream of p38 in psoriasis. J Invest Dermatol 126:1689-1691

26. Johansen C, Kragballe K, Westergaard M, Henningsen J, Kristiansen K, Iversen $L$ (2005) The mitogen-activated protein kinases p38 and ERK1/2 are increased in lesional psoriatic skin. Br J Dermatol 152:37-42

27. Moon CK, Park KS, Kim SG, Won HS, Chung JH (1992) Brazilin protects cultured rat hepatocytes from BrCCl3-induced toxicity. Drug Chem Toxicol 15:81-91

28. Hwang GS, Kim JY, Chang TS, Jeon SD, So DS, Moon CK (1998) Effects of brazilin on the phospholipase A 2 activity and changes of intracellular free calcium concentration in rat platelets. Arch Pharm Res 21:774-778

29. Bae IK, Min HY, Han AR, Seo EK, Lee SK (2005) Suppression of lipopolysaccharide-induced expression of inducible nitric oxide synthase by brazilin in RAW 2647 macrophage cells. Eur J Pharmacol 513:237-242

30. Hwang HS, Shim JH (2018) Brazilin and Caesalpinia sappan L. extract protect epidermal keratinocytes from oxidative stress by inducing the expression of GPX7. Chin J Nat Med 16:203-209

31. Rogerio AP, Kanashiro A, Fontanari C, Da Silva EVG, Lucisano-Valim YM, Soares EG, Faccioli LH (2007) Anti-inflammatory activity of quercetin and isoquercitrin in experimental murine allergic asthma. Inflamm Res 56:402-408

32. $X u$ H, He $Y$, Yang $X$, Liang L, Zhan $Z$, Ye $Y$, Sun $L$ (2007) Anti-malarial agent artesunate inhibits TNF-a-induced production of proinflammatory cytokines via inhibition of NF-KB and PI3 kinase/Akt signal pathway in human rheumatoid arthritis fibroblast-like synoviocytes. Rheumatology 46:920-926

33. Yokouchi M, Kubo A, Kawasaki H, Yoshida K, Ishii K, Furuse M, Amagai M (2015) Epidermal tight junction barrier function is altered by skin inflammation, but not by filaggrin-deficient stratum corneum. J Dermatol Sci 77:28-36

34. Cho UM, Choi JH, Hwang HS (2017) Deoxynivalenol impair skin barrier function through the down regulation of filaggrin and claudin 1/8 in $\mathrm{HaCaT}$ keratinocyte. Biotechnol Bioprocess Eng 22:693-699

35. Nakajima K, Sano S (2018) Mouse models of psoriasis and their relevance. J Dermatol 45:252-263

\section{Publisher's Note}

Springer Nature remains neutral with regard to jurisdictional claims in published maps and institutional affiliations. 